\title{
Evaluatıon Of Release Of L-DOPA From PLGA Nanopartıcles With Different In Vitro Relase Methods By An Optımızed HPLC Method
}

\section{Optimize Edilen HPLC Yöntemi ile L-DOPA Yüklü PLGA Nanopartiküllerinden Etkin Madde Salımının Farklı İn Vitro Çıkış Yöntemleri ile Değerlendirilmesi}

id Sema ARISOY, Özgün SAYINER, Tansel ÇOMOĞLU

Ankara University Pharmaceutical Technology, Ankara, Turkey

\begin{abstract}
Objective: Dissolution tests have emerged in the pharmaceutical field as a very important tool to characterize drug product performance. To assure product quality and performance after the manufacturing process, changes in the formulation can be assessed through dissolution tests during the development of new formulations.
\end{abstract}

Methods: In this study, a simple High Performance Liquid Chromatography (HPLC) method was developed and validated for the quantitation of release of L-Dopa from poly (D, L-lactic-coglycolic acid) (PLGA) nanoparticles. Chromatographic separation was done with a reversed-phase C18 column, using acetonitrilewater containing $0,05 \%$ trifluoroacetic acid $(5: 95, \mathrm{v} / \mathrm{v})$ as a mobile phase at a wavelength of $280 \mathrm{~nm}$. The developed method was validated according to ICH guidelines for its specificity, linearity, accuracy, and precision.

Results: The method was shown to be linear $(\mathrm{r} 2 \geq 0.995)$ over the concentration range of $1,25-40 \mu \mathrm{g} / \mathrm{mL}$. The mean \% recoveries were in between, $102.59 \%-98.70 \%$ indicating an agreement between the true value and the detected value. Solution stability was guaranteed with antioxidant addition. The analytical method was shown to be suitable for the evaluation of L-Dopa which is released from nanoparticles. In vitro release studies were performed using sample and separate (SS), and dialysis membrane (DM) methods. Difference $(f 1)$ and similarity $(f 2)$ factors were used in the comparison of the SS and DM methods. The difference in the

\section{ÖZ}

Amaç: Farmasötik alanda çözünme hızı testleri, ilaç ürün performansını karakterize etmek için önemli parametrelerdendir. Üretim sürecinden sonra ürün kalitesini ve performansını sağlamak için, formülasyondaki değişiklikler, yeni formülasyonların geliştirilmesi sırasında çözünme testleriyle değerlendirilebilir.

Yöntemler: Bu çalışmada, poli (D, L-laktik-ko-glikolik asit) (PLGA) nanopartiküllerinden salınan L-Dopa miktarının belirlenmesi için Yüksek Basnıçlı Sıvı Kromatografisi (HPLC) yöntemi geliştirilmiş ve onaylanmıştır. $280 \mathrm{~nm}$ dalga boyunda hareketli faz olarak \% 0.05 trifloroasetik asit $(5: 95, \mathrm{~h} / \mathrm{h})$ içeren asetonitril-su kullanılarak, ters fazlı C18 kolonu ile kromatografik ayırma yapılmıştır. Geliştirilen yöntem, özgünlüğü, doğrusalllğı, doğruluğu ve kesinliği için ICH kurallarına göre doğrulanmışır.

Bulgular: Yöntemin $1.25-40 \mu \mathrm{g} / \mathrm{mL}$ konsantrasyon aralığında doğrusal $(r 2 \geq 0,995)$ olduğu gösterilmiştir. Ortalama \% geri kazanım, \% 102.59- \% 98.70 arasında olup, gerçek değer ile tespit edilen değer arasında bir korelasyon olduğu belirlenmiştir. Antioksidan ilavesiyle çözelti stabilitesi sağlanmışıır. Analitik yöntemin nanopartiküllerden salınan L-Dopa’nın değerlendirilmesi için uygun olduğu gösterilmiş̧tir. Örnek ve ayırma (SS) ve diyaliz membranı (DM) yöntemleri kullanılarak in vitro salım çalışmaları yapılmışıır. SS ve DM yöntemlerinin karş̧laştırılmasında farklılık $(f 1)$ ve benzerlik $(f 2)$ faktörleri kullanılmıştır. L-Dopa salım kinetiğindeki fark her iki yöntem için de anlamlı bulunmamışır $(f 1<15$ ve $f 2>50)$.

Address for Correspondence/Yazışma Adresi: Tansel ÇOMOĞLU, Ankara University Pharmaceutical Technology, Ankara, Turkey

E-mail: tcomoglu@yahoo.com ORCID ID: orcid.org/0000-0002-4221-5814

Received/Geliş Tarihi: 07.11.2019 Accepted/Kabul Tarihi: 10.02.2020

Cite this article as: Arısoy S, Sayıner O, Çomoğlu T. Evaluatıon Of Release Of L-DOPA From PLGA Nanopartıcles With Different In Vitro Relase Methods By An Optımızed HPLC Method. Bezmialem Science. 
L-Dopa release kinetics were not significant for both methods $(f 1$ $<15$ and $f 2>50$ ).

Conclusion: Dissolution test method was compared and an analytical method procedure by HPLC were optimizated and validated for the dissolution of L-Dopa loaded nanoparticles.

Keywords: Analytical validation, L-Dopa, PLGA nanoparticles, in vitro drug release, sample and seperation method, dialysis membran method.
Sonuç: Bu çalışmada, L-Dopa yüklü nanopartiküllerden etkin madde salımının değerlendirilmesi için stabilite testleri de dahil olmak üzere bir çözünme testi yöntemleri karşılaştırılmış ve salınan L-Dopa miktarının tespiti için HPLC yöntemi optimize edilmiş ve valide edilmiştir.

Anahtar Sözcükler: Analitik validasyon, L-Dopa, PLGA nanopartikül, in vitro ilaç salımı, örnek ve ayırma yöntemi, diyaliz membran yöntemi.

\section{INTRODUCTION}

Parkinson's disease (PD) is a chronic disorder which has a progressive and neurodegenerative effect on the movement and expression responsible neurons, and can be defined as a progressive disease which affects dopaminergic neurons, especially nigrostriatal area and surrounding pathways. Recent data suggests that $1-3 \%$ of population in the age range over 65 years of all races is suffering from $\mathrm{PD}(1,2)$. PD's conventional treatment is based on replacing dopamine in living neurons by administering L-Dopa which is the most commonly used dopamine precursor. Conventional therapy has some disadvantages such as fluctuant plasma levels of L-Dopa because of irregular gastric emptying and intermittent oral intake (3), poor relative bioavailability $(\sim 5-15 \%)$, and less than $1 \%$ of the administered dose reaching to the brain (4-7).

Polymeric nanoparticles are prepared with natural or synthetic polymers. In recent studies, the most commonly used nanoparticles produced from biodegradable and biocompatible polymers such as PLGA or poly(glycolic acid). Nanoparticles are preferred due to their ability to provide high chemical and biological resistance, to carry both hydrophilic and lipophilic active substances, and to be given to the body in different ways.

Nanoparticles release small amounts of encapsulated drugs as a function of time, analytical method must be very sensitive to quantify drug concentrations in the dissolution medium during in vitro release experiments. In vitro dissolution/release testing methods for nanoparticulate delivery systems can be broadly divided into three categories: i) membrane diffusion methods (such as the dialysis methods) (DM); ii) sample and separation methods (SS); and iii) continuous flow methods. DM, the most commonly used method to perform in vitro release studies from nanoparticles was chosen as reference method. SS, second common used method was chosen as test method in our study design.

Among the analytical methods currently available, HPLC is one of the most common analytical methods used for the characterization of pharmaceuticals. HPLC-diode array detector (DAD), offers a quick, sensitive and accurate method to separate and identify drugs in pharmaceutical nanoparticle formulations $(8,9)$. Although many researchers have investigated the in vitro drug release from nanoparticles, there aren't any known HPLC method for the simultaneous determination of L-Dopa has been developed and applied for the quantification of released L-Dopa from nanoparticles in dissolution medium,-with the help of DM and SS methods. Also, in most of the reported studies, L-Dopa solutions with low $\mathrm{pH}$ level were used as standart solution(10-13).

Nanoparticles were designed to be transported to brain via nasal route by endocytosis. To demonstrate the dissolution profile of L-Dopa from nanoparticles two buffered solutions that mimic endolisosomal compartment's and brain $\mathrm{pHs}(\mathrm{pH} 4,5$ and $\mathrm{pH}$ 7,4) were used (14). As mentioned before, literature studies about the determination of L-Dopa in acidic solutions provides information that L-Dopa is stable in acidic conditions $(10,12$, $13,15)$. Therefore, we optimizated stability indicated analytical method to determine L-Dopa amount in different media which has higher $\mathrm{pH}$ values as difference to literatures.

Nanoparticles were prepared by double emulsion-solvent evaporation method, using methylene chloride as organic solvent, polyvinyl alcohol as surfactant and PLGA as the polymer in our work. In order to determine the release profile of L-Dopa from PLGA nanoparticles, SS and DM methods were compared. In vitro release method is thought to signify the influence of changes in the manufacturing procedure on the formulation to characterize drug product performance. So in vitro dissolution test methods used was compared and HPLC method validated to ensure the robustness of the analytical method developed, including stability tests of the L-Dopa.

\section{METHODS}

\section{Instrumentation}

Agilent 1100 series integrated HPLC system with DAD, pump, auto-sampler and degasser unit were used for this experiment. $250 \mathrm{~mm} \times 4.6 \mathrm{~mm}, 5 \mu$ reverse-phase C18 HPLC column was from Macherey-Nagel. Orbital shaker and ultra centrifuge (Sigma ${ }^{\oplus} 30 \mathrm{KS}$ ) were used for in vitro drug release studies.

\section{Reagents and materials}

L-Dopa was gift from ILKO Pharmaceuticals (Ankara, Turkey). Deionised water was acquired from a Millipore water supplier. Trifluoroacetic acid (TFA), NaCl, Na2HPO4, KH2PO4, Acentonitrile (HPLC grade) and Tween 80 were from Merck. The mobile phase was filtered through a $0.45 \mathrm{~mm}$ membrane filter (Millipore, Barcelona) and degassed with ultrasonic bath, prior to use. Dialysis tubing cellulose (14,000 MWCO) and Polypropylene co-Polymer centrifuge tubes were supplied by Sigma-Aldrich. Poly (vinyl alcohol) (PVA) were from Sigma-Aldrich. 


\section{Chromatographic system and conditions}

Wavelength was selected based on absorbance maximization of the drug as per UV spectrum. $280 \mathrm{~nm}$ was found ideal for L-Dopa for HPLC analysis. Mobile phase was comprised of TFA solution (\% 0,05 v/v) pH 3 - acetonitrile (95:5). $250 \mathrm{~mm} \times$ $4.6 \mathrm{~mm}, 5 \mu \mathrm{C} 18 \mathrm{HPLC}$ column was used for chromatographic separation. Flow rate was $1 \mathrm{~mL} / \mathrm{min}$ and run time was 7 minutes with $10 \mu \mathrm{L}$ injection volume (1). The present method was developed and validated in consideration of the $\mathrm{ICH}$ guideline Q2 (R1) consisting the following parameters: specificity, linearity, detection and quantification limits, repeatability and intermediate precision, accuracy and stability (16).

\section{Preparation of working solutions}

Suitable analytical procedures should be applied for defining of the amount of L-Dopa dissolved during dissolution test. $100 \mu \mathrm{g} /$ $\mathrm{mL}$ stock solution were prepared by dissolving a suitable amount of L-Dopa in buffer solutions $\mathrm{pH} 4.5$ and $\mathrm{pH}$ 7.4. All solutions were sonicated for $30 \mathrm{~min}$ before use. 6 concenration point range of $1,25-2,5-5-10-20-40 \mu \mathrm{g} / \mathrm{mL}$ (ppm) was constructed by diluting from stock solutions with buffer solutions $\mathrm{pH} 4.5$ and $\mathrm{pH} 7.4$ For Stability of L-Dopa in diluents(phosphate buffer solution $\mathrm{pH} 4.5$ and $\mathrm{pH} 7.4$ ) was investigated for over 48 hours at different tempratures $\left(4^{\circ} \mathrm{C}, 25^{\circ} \mathrm{C}, 37^{\circ} \mathrm{C}\right)$ in presence and absence of ascorbic acid.

\section{Preparation of nanoparticles}

L-Dopa loaded nanoparticles were prepared using a double emulsion solvent evaporation method using PVA as a stabilizer. Briefly, L-Dopa and PLGA were dissolved in dichloromethane (DCM), and distilled water was added to that solution and by means of using an ultrasonic homogenizer they were mixed to form a primary W/O emulsion. The primary emulsion was further emulsified in PVA solution by homogenization to obtain a double $\mathrm{W}_{1} / \mathrm{O} / \mathrm{W}_{2}$ emulsion. The resultant double emulsion was then stirred at a certain rate at room temperature $\left(25^{\circ} \mathrm{C}\right)$ on a magnetic stirring plate to evaporate the organic solvent. The resulting nanoparticle suspension was kept at $4^{\circ} \mathrm{C}$ overnight to allow hardening of the PLGA matrix by allowing the DCM to fully partition to the external aqueous phase. Nanoparticles was recovered by ultracentrifugation. The supernatant was removed and nanopaticles sediments was washed twice with distilled water to remove free drug and excess surfactant, and then lyophilized.

\section{Dissolution test development}

\section{Dissolution medium}

The term sink conditions is defined as the ability of the dissolution media to dissolve at least 3 times the amount of drug in the dosage form. Percentage of drugs released should be detected with the developed analytical method. Selection of the most suitable media condition is based on stability of the analyte in the test medium, and applicability to in vivo performance. In vitro release of L-Dopa from PLGA nanoparticles was performed in $\mathrm{pH} 4.5$ to mimic the endolysosomal $\mathrm{pH}$ an $\mathrm{pH} 7.4$ to mimic the brain $\mathrm{pH}$ as the nanoparticles were designed to target brain with endocytosis after nasal administration (17). Phosphate buffer solution $\mathrm{pH} 4.5$ was prepared as dissolving $6,8 \mathrm{~g}$ potasium dihydrojen phosphate, $2 \%$ Tween $80,0.1 \%$ ascorbic acid (aa) in $1000 \mathrm{~mL}$ distilled water and phosphate buffer solution $\mathrm{pH} 7.4$ was prepared as dissolving $2,38 \mathrm{~g}$ disodium hydrogen phosphate, $0,19 \mathrm{~g}$ potassium dihydrogen phosphate, $8 \mathrm{~g}$ sodium chloride, 2 $\%$ Tween $80,0.1 \%$ aa in $1000 \mathrm{~mL}$ distilled water. $2 \%(\mathrm{w} / \mathrm{v})$ Tween 80 was used to enhance the solubility of L-Dopa in aqueous solution. $0,1 \%(\mathrm{w} / \mathrm{v})$ ascorbic acid was added to protect L-Dopa from oxidation during study (18).

\section{Method devolopment}

\section{In vitro drug release (SS method)}

L-Dopa loaded nanoparticles weighed to contain $45 \mu \mathrm{g}$ L-Dopa were suspended in $5 \mathrm{~mL}$ of buffer solution. The suspension were poured in tubes and placed in an orbital shaker bath which was maintained at $37 \pm 0.5^{\circ} \mathrm{C}$ with a rotation of $100 \mathrm{rpm}$. At 30, $60,120,240$ minutes, the tubes were taken out of the water bath and centrifuged 20 minutes at $2000 \mathrm{rpm}$. The precipitated nanoparticles were resuspended in $5 \mathrm{~mL}$ of fresh buffer $(\mathrm{pH} 4.5)$ and then put back in the shaker bath. The supernatant was taken for determination of L-Dopa concentration. All experiments were done in triplicate and results were given with variations.

\section{In vitro drug release (DM method)}

L-Dopa loaded nanoparticles; containing $45 \mu \mathrm{g}$ L-Dopa were suspended in $0,5 \mathrm{~mL}$ of buffer solution and was inserted in a dialysis bag. The dialysis bag was put in $4,5 \mathrm{~mL}$ (total $5 \mathrm{~mL}$ ) buffer solution at $\mathrm{pH} 4.5$ and placed in an orbital shaker bath which was maintained at $37 \pm 0.5^{\circ} \mathrm{C}$ with a rotation of $100 \mathrm{rpm}$. At 30,60 , 120, 240 minutes $1 \mathrm{~mL}$ aliquots were taken and replaced with 1 $\mathrm{mL}$ fresh $\mathrm{pH} 4.5$ buffer. Drug concentrations were determined with the given analytical method. All experiments were done in triplicate. Results were given with variations.

\section{Statistical calculations}

All results are reported with mean and standard deviation of replicates. At all time intervals drug release (\%) were discussed using two tailed t-test with Prism Software Version 6.0 a considering significant differences with $\mathrm{p}<0.05 . f 1$ and $f 2$ factor were calculated by using Microsoft Office Excel ${ }^{\oplus}$.

\section{RESULTS}

Mobile phase was comprised of TFA solution (\% $0.05 \mathrm{v} / \mathrm{v}) \mathrm{pH} 3$ - acetonitrile (95:5). $250 \mathrm{~mm} \times 4.6 \mathrm{~mm}, 5 \mu \mathrm{C} 18 \mathrm{HPLC}$ column was used for chromatographic separation. Flow rate was $1 \mathrm{~mL} /$ min and run time was 7 minutes with $10 \mu \mathrm{L}$ injection volume. No interfence was observed after enjection of L-Dopa solution, placebo and nanoparticles,

The regression equations for the calibration curve was found to be $y=5.7424 x+2.1421$ (Figure 3) for phosphate buffer solution $\mathrm{pH} 4.5$ and $\mathrm{y}=7.4159 \mathrm{x}+9,5333$ (Figure 4) for phospate buffer saline solution $\mathrm{pH} 7.4$. The regression coefficient $\mathrm{r}^{2}$ was 0.9998 for $\mathrm{pH} 4.5,0.995$ for $\mathrm{pH} 7.4$ solution. Linearty datas 
was calculated with Prism Software Version 6.0 as sown in Table 1. RSD \% of repeatability analysis in $\mathrm{pH} 4.5$ buffer solution was between $3.07 \%-0.03 \%$. For $\mathrm{pH} 7.4 \mathrm{RSD} \%$ values was between $0.83 \%-0.01 \%$. The result revealed the precision with RSD \%, $1.44 \%$ to $0.01 \%$ for $\mathrm{pH} 4.5$ and $1.00 \%$ and $0.01 \%$ for $\mathrm{pH} 7.4$, respectively for inter day. The mean \% recoveries were in between $102.59-98.70$ for $\mathrm{pH} 4.5$ and 101.92-100.00 for $\mathrm{pH}$ 7.4. $\mathrm{L}_{\mathrm{D}}$ and $\mathrm{L}_{\mathrm{Q}}$ values for $\mathrm{pH} 4.5$ was found to be 0 . $0408,0.1235 \mu \mathrm{g} / \mathrm{ml}$ and for $\mathrm{pH} 7.4$ was found to be 0.0636 , $0.1928 \mu \mathrm{g} / \mathrm{ml}$ respectively. It was found that remaining L-Dopa was $97.46 \%$ at $4^{\circ} \mathrm{C}, 95.54 \%$ at $25^{\circ} \mathrm{C}, 89.63 \%$ at $37^{\circ} \mathrm{C}$ for $\mathrm{pH} 4.5$ solutioun in precense of ascorbic acid for 48 hours. It was found that remaining L-Dopa was $103.21 \%$ at $4^{\circ} \mathrm{C}, 88.21$ $\%$ at $25^{\circ} \mathrm{C}, 75.85 \%$ at $37^{\circ} \mathrm{C}$ in $\mathrm{pH} 7.4$ solutioun in precense of ascorbic acid for 48 ours.

The release rate differences were evaluated for SS and DM method. $f 1$ was found 6.02 and $f 2$ was found 95.38 At all time intervals drug release (\%) was not different between test and reference methods $(\mathrm{p}=0.853 ; \mathrm{p}<0.05)$.

\section{DISCUSSION}

\section{Optimization of the chromatographic method}

The HPLC method was developed for the determination of drugs was able to sustain a reliable quality control analysis. The wavelength was selected based on absorbance maxima of three different concentrations of L-Dopa solutions as per UV spectrum. A wavelength of $280 \mathrm{~nm}$ was selected because it provides high sensitivity which is needed for the quantitation of significantly low drug concentrations in the dissolution samples.

To determine the peak of L-Dopa, mobile phase has to have the

\begin{tabular}{l|l|l|}
\hline \multicolumn{3}{|c}{ Table 1. Linearty Data of Analytical Method } \\
\hline Values & $\mathrm{pH} 4.5$ & $\mathrm{pH} 7.4$ \\
\hline Slope & 5.742 & 7.416 \\
\hline $\begin{array}{l}\text { Standard deviation of slope } \\
\text { Confidence interval 95\% }\end{array}$ & 0.02059 & 0.1312 \\
\hline $\begin{array}{l}\text { Correlation coefficient } \\
\text { Regression coefficient }\end{array}$ & $5.699-5.786$ & $4.679-4.896$ \\
$\begin{array}{l}\text { Intercept } \\
\text { Standard deviation of }\end{array}$ & 0.9999 & 0.9975 \\
\hline $\begin{array}{l}\text { Intercept } \\
\text { Confidence interval of }\end{array}$ & 2.142 & 0.9950 \\
Intercept & 0.3595 & -9.533 \\
\hline
\end{tabular}

adequate polar:apolar solvent ratio. Some important parameters such as the $\mathrm{pH}$ of the mobile phase, percentage of organic modifier were tested for an acceptable chromatographic separation. Experiments was conducted with $1 \mathrm{~mL} / \mathrm{min}$ flow rate, 7 minutes run time and $10 \mu \mathrm{L}$ injection volume. $10 \mathrm{ppm}$ concentration L-Dopa was given the system as sample. Experiments showed that acidic mobile phase with reverse phase $\mathrm{C} 18$ column provides symmetric and sharp peaks and provides high solubility for L-Dopa. Therefore TFA solution was determined as acidic buffer solution as shown Figure1.Zhou, Alany, Chuang, Wen ${ }^{1}$

When the ratio of mobile phase was formed with acetonitrile- $0.05 \%(\mathrm{v} / \mathrm{v})$ TFA solution $(5: 95 \mathrm{v} / \mathrm{v})$ from $(10: 90$, $\mathrm{v} / \mathrm{v})$ the peak of active subtance was cracked. Acetonitrile- $0.05 \%$ $(\mathrm{v} / \mathrm{v})$ trifluoroacetic acid solution $(2.5: 97.5, \mathrm{v} / \mathrm{v})$ ratio for mobile phase was tested for a better separation. However, peak of L-Dopa couldn't be determined quite contrary to our previous experiments. To protect the column's integrity, TFA solution was adjusted at $\mathrm{pH} 3$ with $0,1 \mathrm{~N} \mathrm{HCl}$ acid solution and peak tailing was acceptable (Figure 1).

The symmetry factors obtained for the sample peak (1.058) was determined in the limits $<1.5$ of various pharmacopeias (Figure 1). Therefore, the HPLC analysis parameters were settled as

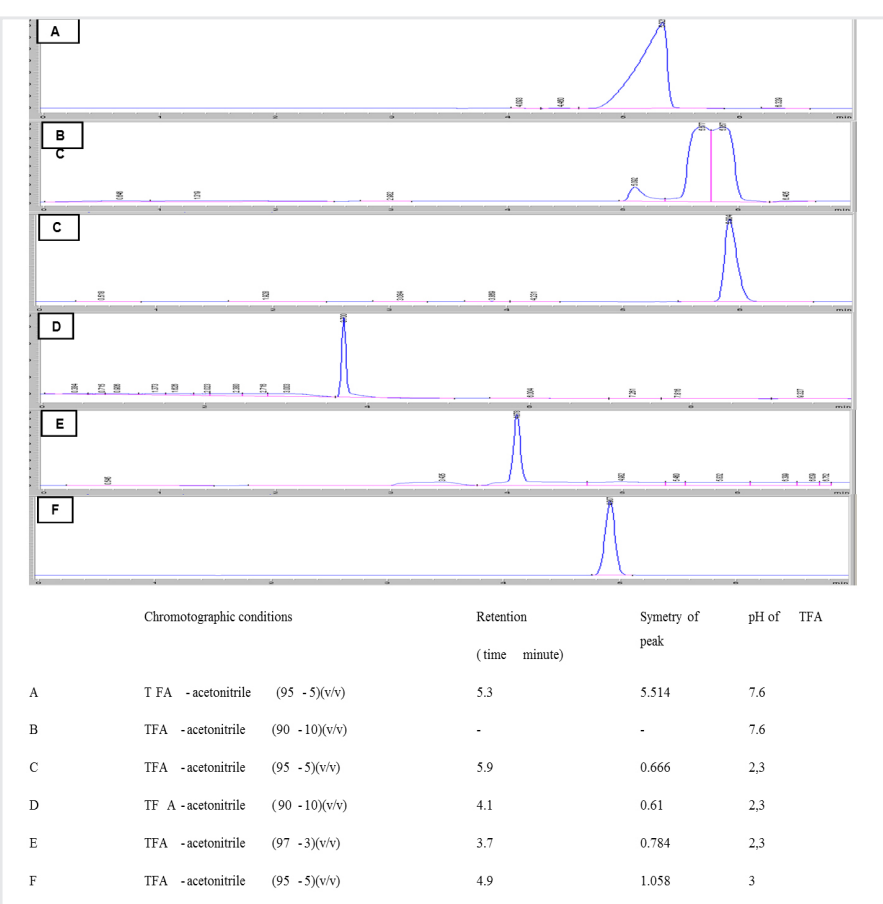

Figure 1. Preliminary chromatogram with C18 phase

Table 2: Repeatability analysis of the assay in $\mathrm{pH} 4.5$ buffer solution for HPLC ( $n=6)$

\begin{tabular}{|c|c|c|c|c|c|}
\hline \multicolumn{2}{|l|}{$1.25 \mu \mathrm{g} / \mathrm{mL}$} & \multicolumn{2}{|l|}{$5 \mu \mathrm{g} / \mathrm{mL}$} & \multicolumn{2}{|l|}{$20 \mu \mathrm{g} / \mathrm{mL}$} \\
\hline Area & Concentration $\mu \mathrm{g} / \mathrm{mL}$ & Area & Concentration $\mu / \mathrm{gL}$ & Area & Concentr \\
\hline Average & 1.24863 & Average & 5.12961 & Average & 19.73933 \\
\hline SD & 0.04 & SD & 0.03 & SD & 0.13 \\
\hline RSD & 3.07 & RSD & 0.50 & RSD & 0.68 \\
\hline
\end{tabular}


$250 \mathrm{~mm} \times 4.6 \mathrm{~mm}, 5 \mu \mathrm{C} 18 \mathrm{HPLC}$ column for chromatographic separation with a rate of $1 \mathrm{~mL} / \mathrm{min}$ flow with 7 minutes run time, $10 \mu \mathrm{L}$ injection volume, $25^{\circ} \mathrm{C}$ column temprature and acetonitrile- $0.05 \%(\mathrm{v} / \mathrm{v})$ TFA solution $(5: 95, \mathrm{v} / \mathrm{v})(\mathrm{pH} 3)$ for mobile phase (1).

Nanoparticles were designed to be transported to brain via nasal route by endocytosis. To demonstrate the dissolution profile of L-Dopa from nanoparticles two buffered solutions that mimic endolisosomal compartment's and brain $\mathrm{pHs}(\mathrm{pH} 4.5$ and $\mathrm{pH}$ 7.4) were used (14). As mentioned before, literature studies about the determination of L-Dopa in acidic solutions provides information that L-Dopa is stable in acidic conditions $(10,12$, 13, 15). Therefore, we optimizated stability indicated analytical method to determine L-Dopa amount in different media which has higher $\mathrm{pH}$ values as difference to literatures. In addition, $\mathrm{pH}$ 4.5 and $\mathrm{pH} 7.4$ buffer solution with and without L-Dopa are injected to determine whether there is interference in the peaks. Any interfenrence was observed (Figure 2).

\section{Method validation}

The present method was developed and validated in accordance with the ICH guideline Q2 (R1)(16). The most widely applied validation characteristics; linearity, accuracy, precision, specificity, stability, detection limit and quantification limit were performed. The method was then utilised to quantificate of released drug amount from nanoparticles containing L-Dopa.

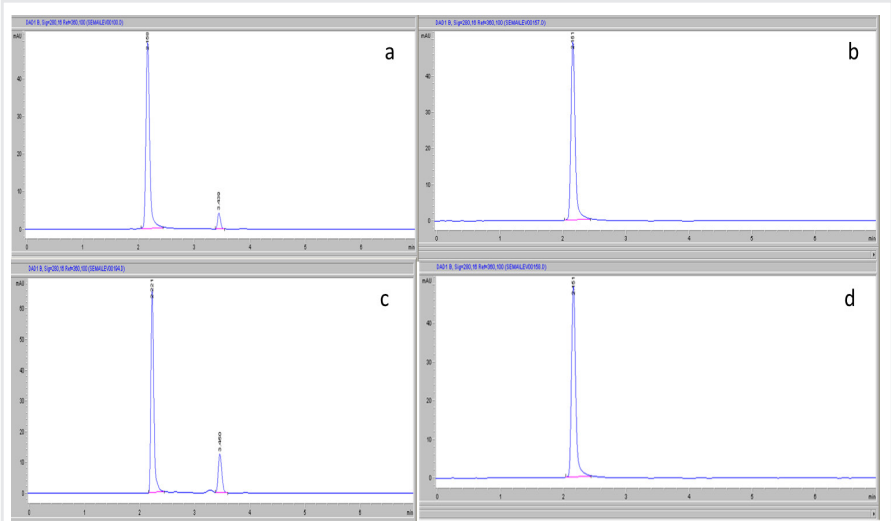

Figure 2. a) Chromatogram of L-Dopa in ph 4.5 solution, b) Chromatogram of $\mathrm{pH} 4.5$ solution, c) Chromatogram of L-Dopa in ph 7.4 solution, d) Chromatogram of $\mathrm{pH} 7.4$ solution

\section{Linearity}

Linearity was studied by preparing standard solutions at different concentration levels. ICH guidelines specify a minimum of five concentration levels, linearity was determined for L-Dopa in the range of $1.25-40 \mu \mathrm{g} / \mathrm{mL}$ at six concentration levels by performing three independent repetitions $(\mathrm{n}=3)$ (16). Samples were analysed six times per concentration; peaks areas were documented, analysed and results of the regression statistics are given in Figures 3 and 4 . A good linear relationship $\left(r^{2} \geq 0.995\right)$ was observed between the concentrations and the respective peak areas provided by the detector (Figures $3 \& 4$ ). The regression coefficient $\mathrm{r}^{2}$ is $\geq 0.995$ considered as evidence of acceptable fit

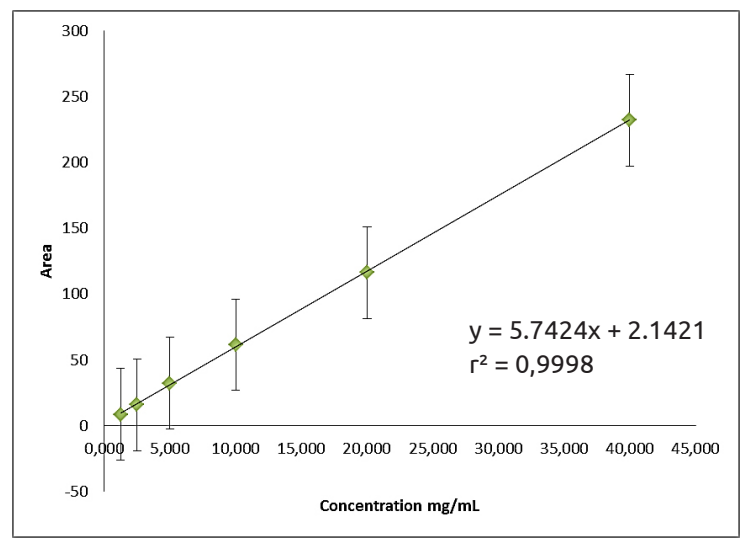

Figure 3: Calibration curve of L-Dopa in $\mathrm{pH} 4.5$ buffer solution for HPLC $(n=3)$

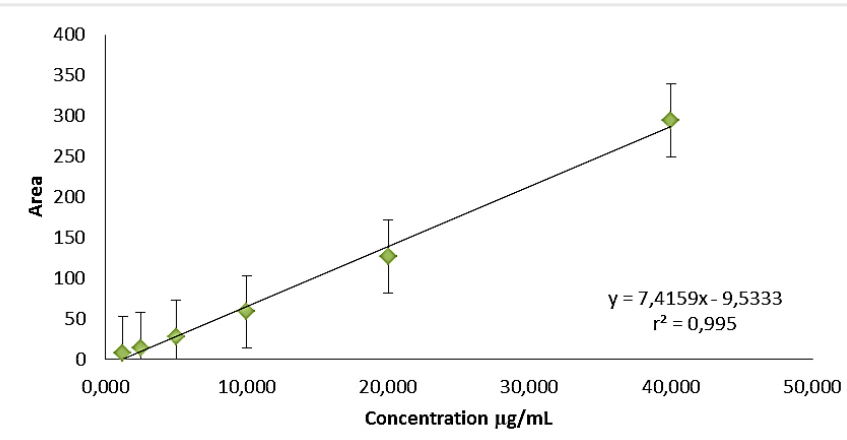

Figure 4: Calibration curve of L-Dopa in $\mathrm{pH} 7,4$ buffer solution for HPLC $(n=3)$

Table 3: Repeatability analysis of the assay in pH 7.4 buffer solution for HPLC ( $n=6)$

\begin{tabular}{|c|c|c|c|c|c|}
\hline \multicolumn{2}{|c|}{$1.25 \mu \mathrm{g} / \mathrm{mL}$} & \multicolumn{2}{|l|}{$5 \mu \mathrm{g} / \mathrm{mL}$} & \multicolumn{2}{|l|}{$20 \mu \mathrm{g} / \mathrm{mL}$} \\
\hline Area & Concentration $\mu / \mathrm{gL}$ & Area & Concentration $\mu \mathrm{g} / \mathrm{mL}$ & Area & Concentration $\mu \mathrm{g} / \mathrm{mL}$ \\
\hline Average & 1.31923 & Average & 5.00051 & Average & 18.49404 \\
\hline SD & 0.01 & SD & 0.04 & SD & 0.10 \\
\hline RSD & 0.56 & RSD & 0.83 & RSD & 0.53 \\
\hline
\end{tabular}


of the data to the regression line according to the $\mathrm{ICH}$ guidelines (16). Acceptability of linearity data is often judged by examining the correlation intercept. Also slope of line should be calculated for better analysis (Table 1) (8). These results show us that all calibration curves have suitable linearity according to ICH guidlines (16).

\section{Precision}

The absolute difference values between the mean assay results obtained from the repeatability and intermediate precision tests meet the acceptance criteria (\% relative standard deviation $(\mathrm{RSD})<2.0)$. Repeatability, establishes the precision of multiple sampling under the same operating conditions over a short interval time, while intermediate precision establishes variations from the same laboratory under variable operation conditions, for example different days, analysts or equipment. Hence, the method was found precise (19).

\section{Repeatability}

Repeatability prove precision under the same operational conditions over a short period of time. Repeatability is also attributed to as intra-assay sensitivity. In this study; low $(1.25 \mu \mathrm{g} /$ $\mathrm{mL})$, medium $(5 \mu \mathrm{g} / \mathrm{mL})$ and high $(20 \mu \mathrm{g} / \mathrm{mL})$ concentrations representing the calibration curve were analyzed to determine mean, standard deviation (SD) and RSD ( $n=6)$. RSD \% for standart peak must be lower than 2.0 (20). The results in Tables 2\&3 show that the method meets the requirements of this analytical validation parameter for medium $(5 \mu \mathrm{g} / \mathrm{mL})$ and high $(20 \mu \mathrm{g} / \mathrm{mL})$ concentrations (20). Replication of $1.25 \mu \mathrm{g} /$
$\mathrm{mL}$ which represents the lower concentration, \%RSD was higher than 2.0. However, there are also a number of literature that extend the limits to 5-6\% (8). The concentration $1.25 \mu \mathrm{g} / \mathrm{mL}$ represents the lowest point of calibration curve, so extension of limits seems suitable for this method.

\section{Intermediate precision}

The analyst variations of the method were determined using replicate injections of the concentrations given below and analyzed with different analysts on the same day (Tables 4\&5). Intermediate precision was performed by RSD \% of six repetated assays on samples at three concentration levels. RSD \% values were found for all concentration levels and $\mathrm{pH}$ s to be $1,44 \%$ and $0,1 \%$. For intermediate precision, the RSD \% value should not exceed $2.0 \%$ The results in Tables 4 and 5 show that the method meets the requirements of this analytical validation parameter (16).

\section{Accuracy}

The accuracy was determined by recovery of known amounts of L-Dopa. For the purpose of testing the accuracy of analytical methods, three concentrations $(1.25 ; 5 ; 20 \mu \mathrm{g} / \mathrm{mL}$; the low, medium, high concentrations, respectively) were diluted from stock solutions, covering the linear range of analytes were used. The mean \% recoveries were in between 101.92-98.70\% implying an agreement between the true value and the found value (Table 6-7). All results meet the requirements for method verification according to the ICH guidelines (16).

Table 4: Precision analysis of the assay in $\mathrm{pH} 4.5$ buffer solution for HPLC $(n=6)$

\begin{tabular}{|c|c|c|c|c|c|c|}
\hline & $1.25 \mu \mathrm{g} / \mathrm{mL}$ & & $5 \mu \mathrm{g} / \mathrm{mL}$ & & $20 \mu \mathrm{g} / \mathrm{mL}$ & \\
\hline & 1. Day & 2. Day & 1. Day & 2. Day & 1. Day & 2. Day \\
\hline Average & 1.2128 & 1.19172 & 5.12961 & 4.89316 & 20.6562 & 20.6382 \\
\hline RSD & 1.44 & 1.58 & 0.5 & 1 & 0.66 & 0.1 \\
\hline
\end{tabular}

Table 5: Precision analysis of the assay in $\mathrm{pH} 7.4$ buffer solution for $(n=6)$

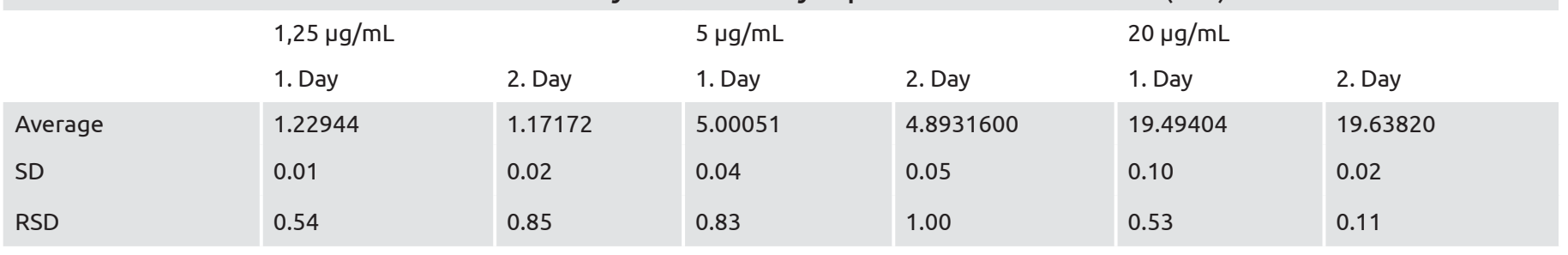

Table 6: Accuracy analysis of the assay in pH 4.5 buffer solution for HPLC $(n=6)$

\begin{tabular}{|c|c|c|c|c|c|}
\hline \multicolumn{2}{|l|}{$1.25 \mu \mathrm{g} / \mathrm{mL}$} & \multicolumn{2}{|l|}{$5 \mu \mathrm{g} / \mathrm{mL}$} & \multicolumn{2}{|l|}{$20 \mu \mathrm{g} / \mathrm{mL}$} \\
\hline $\begin{array}{l}\text { Experimental } \\
\text { Concentration }\end{array}$ & \% Recovery & $\begin{array}{l}\text { Experimental } \\
\text { Concentration }\end{array}$ & \% Recovery & $\begin{array}{l}\text { Experimental } \\
\text { Concentration }\end{array}$ & \% Recovery \\
\hline Average & 99.89 & Average & 102.59 & Average & 98.70 \\
\hline SD & 1.06 & SD & 0.51 & SD & 0.67 \\
\hline RSD & 1.07 & RSD & 0.50 & RSD & 0.68 \\
\hline
\end{tabular}




\section{Specificity}

Specificity can be defined as the analyte being assessed precisely in the presence of expected components. This definition has a descriptive effect on the identity of an analyte. In our study, specificity tests were performed using three different polymers prepared nanoparticles and L-Dopa in two media. It was decided that the HPLC method was specific for the determination of L-Dopa according to the data obtained in Table 8. L-Dopa samples were injected five times and the similar retention times were observed in all cases. All prepared nanoparticles with different polymer subtances were injected with or without L-Dopa. Any interference was not observed between the peaks of nanoparticles and L-Dopa. As a result the described HPLC method was specific for $\mathrm{pH} 7.4$ and selective for $\mathrm{pH} 4.5$ solutions.

\section{Stability}

The stability of L-Dopa in aqueous solution was evaluated to verify that if any spontaneous degradation occur when the samples were prepared (21). The aqueous solutions of L-Dopa were found to be unstable. However, aqueous solutions have been proven to be stable in the presence of high concentrations of acidic substances. Stability of L-Dopa was not affected by light. The storage condition for the active substance was specified as $2-8^{\circ} \mathrm{C}$. In addition, it has been proven that in the presence of antioxidants, L-Dopa can be protected from oxidation. Therefore, we planned to obtain information about the stability of L-Dopa in the presence of ascorbic acid in the body and during the validation and formulation studies $(3,18,22) .0 .4$ $\mathrm{mg} / \mathrm{mL}$ L-Dopa containing stock solutions were prepared with $\mathrm{pH} 4.5$ and $\mathrm{pH} 7.4$ buffered solutions. The solutions were mixed and vortexed until solid particles disappeared, then separated into $3 \mathrm{~mL}$ aliquots. The stability of the solutions containing ascorbic acid was extended up to 48 hours. Any oxidation was not observed in aa containing solutions at $4^{\circ} \mathrm{C}$. As a result of the study, it is clarified that ascorbic acid should be added as a preserving agent in dissolution medium to perform the dissolution studies. Interference was not observed between peak of L-Dopa and ascorbic acid. The results are given in Table 9-10.

Table 7: Accuracy analysis of the assay in pH 7.4 buffer solution for HPLC ( $n=6)$

\begin{tabular}{|c|c|c|c|c|c|}
\hline \multicolumn{2}{|l|}{$1.25 \mu \mathrm{g} / \mathrm{mL}$} & \multicolumn{2}{|l|}{$5 \mu \mathrm{g} / \mathrm{mL}$} & \multicolumn{2}{|l|}{$20 \mu \mathrm{g} / \mathrm{mL}$} \\
\hline $\begin{array}{l}\text { Experimental } \\
\text { Concentration }\end{array}$ & \% Recovery & $\begin{array}{l}\text { Experimental } \\
\text { Concentration }\end{array}$ & \% Recovery & $\begin{array}{l}\text { Experimental } \\
\text { Concentration }\end{array}$ & \% Recovery \\
\hline Average & 101.92 & Average & 100.00 & Average & 100.01 \\
\hline SD & 0.74 & SD & 0.81 & SD & 0.83 \\
\hline RSD & 0.56 & RSD & 0.81 & RSD & 0.83 \\
\hline
\end{tabular}

Table 8. The results of specificity analysis of HPLC method for L-Dopa

\begin{tabular}{|c|c|c|c|c|}
\hline & \multicolumn{2}{|l|}{ pH 4.5} & \multicolumn{2}{|l|}{ pH 7.4} \\
\hline & $\begin{array}{l}\text { Time } \\
\text { (minute) }\end{array}$ & Area & $\begin{array}{l}\text { Time } \\
\text { (minute) }\end{array}$ & Area \\
\hline L-Dopa & 4.2 & 42.7 & 3.93 & 39.9 \\
\hline Resomer RG 503 H Nanoparticles & 2.3 & 10 & 0 & 0 \\
\hline Resomer RG 756H Nanoparticles & 2.3 & 8.6 & 0 & 0 \\
\hline Resomer RG 756H Nanoparticles & 2.4 & 9.4 & 0 & 0 \\
\hline
\end{tabular}

Tablo 9. Stability study results of of L-Dopa in pH 4.5 solution (aa= ascorbic acid)

$\mathrm{pH} 4.5$

aa

added

Hours
Temperature
$4^{\circ} \mathrm{C}$
$25^{\circ} \mathrm{C}$
$37^{\circ} \mathrm{C}$

0

\% Drug Content

100.00

100

100 aa

not added

$\%$ Drug Content

\begin{tabular}{l|l}
100.00 & 100.17
\end{tabular}

100.00

100.00
24

100.02

100.05
48

68.37

60.64

55.89 


\section{Limit of detection $\left(\mathrm{L}_{\mathrm{D}}\right)$ and limit of quantification $\left(\mathrm{L}_{\mathrm{Q}}\right)$}

Limit of detection $\left(\mathrm{L}_{\mathrm{D}}\right)$ represents the lowest concentration level in a peak area of three fold of the baseline-to-noise. Limit of quantification $\left(\mathrm{L}_{\mathrm{Q}}\right)$ represents as lowest concentration level that is provided by a peak area with signal-to-noise. Calibration curve was calculated by using concentrations in the range of $1.25-40$ $\mu \mathrm{g} / \mathrm{mL}$. With following equations;

Detection limit $\left(\mathrm{L}_{\mathrm{D}}\right)=3.3 \mathrm{a} / \mathrm{s}$;

Quantification limit $\left(\mathrm{L}_{\mathrm{Q}}\right)=10 \mathrm{a} / \mathrm{s}$;

where $\mathrm{a}$ is the standard deviation of $\mathrm{y}$-intercepts of regression lines and $s$ is the slope of the calibration curve. For $\mathrm{L}_{\mathrm{D}}$ and $\mathrm{L}_{\mathrm{Q}}$, where there isn't any defined limit in literature, are specific for each method. As shown in Table 12, obtained results meet our requirements for in vitro dissolution tests (23).

\section{In vitro drug release}

To design the dissolution media for a poorly soluble drug, the first method is increasing the volume of aqueous sink conditions or decreasing the dissolved drug amount. The addition of anionic or non-ionic surfactans and solubilizing the drug by co-solvents up to $40 \%$ is another used approache. The other approach is to alter the $\mathrm{pH}$ for a better sink condition. The last two approaches seem less cumbersome and have been more widely employed in pharmaceutical dissolution tests. $2 \%$ Tween 80 was used to enhance the solubility of L-Dopa and ascorbic acid was added to the used mediums to protect L-Dopa from oxidation during in vitro release.

The cumulative amount of L-Dopa released from polymeric metarial was plotted as a function of time. As shown in Figure 4 only 5-6\% of the drug content released from nanoparticles for both methods. To achieve sink conditions L-Dopa concentrations shouldn't exceed $20 \%$ of its saturation solubility in dissolution medium like in this study. So the reason for inhibited release was not insufficient sink conditions. Also this was not the case because of the inadequate loading of nanoparticles (amount of released drug as a function of the encapsulated drug substance). Interactions between L-Dopa and PLGA prevented complete dissolution. Moreover, \% 5-6 of the drug content was suitable for dicussion of both methods. In vitro release profiles of the test formulations were similar with the reference formulation. In literature, it is told that release rate of the encapsulated drug is progressively higher when SS method compared with the DM (Figure 5) (24). This might be due to differences in

Tablo 10. Stability study results of L-Dopa in pH 7.4 solution (aa= ascorbic acid)

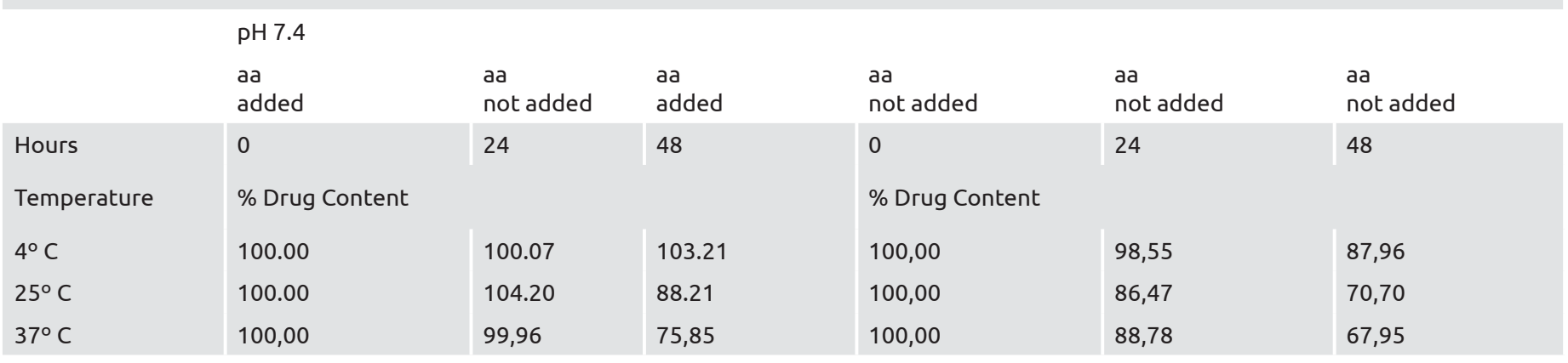

\begin{tabular}{|c|c|c|}
\hline & $\mathrm{L}_{\mathrm{D}}$ & $\mathrm{L}_{\mathrm{Q}}$ \\
\hline $\mathrm{pH} 4.5$ & 0.0408 & 0.1235 \\
\hline $\mathrm{pH} 7.4$ & 0.0636 & 0.1928 \\
\hline
\end{tabular}

Table 12. $f_{1}$ and $f_{2}$ statistics for the dissolution profile using the DM as reference and the SS as test model $(n=3)$

\begin{tabular}{|l|l|l|}
\hline $\begin{array}{l}\text { Time } \\
\text { (minute) }\end{array}$ & $\begin{array}{l}\text { Test Model, Drug } \\
\text { Release (\%) }\end{array}$ & $\begin{array}{l}\text { Reference Model, Drug } \\
\text { Release (\%) }\end{array}$ \\
\hline 30 & $3.73 \pm 0.03$ & $3.81 \pm 0.01$ \\
60 & $5.45 \pm 0.02$ & $5.33 \pm 0.05$ \\
120 & $5.45 \pm 0.02$ & $6.38 \pm 0.01$ \\
240 & $5.45 \pm 0.02$ & $6.38 \pm 0.01$ \\
& $f_{1}$ & 6.02 \\
\hline & $f_{2}$ & 95.38 \\
\hline
\end{tabular}

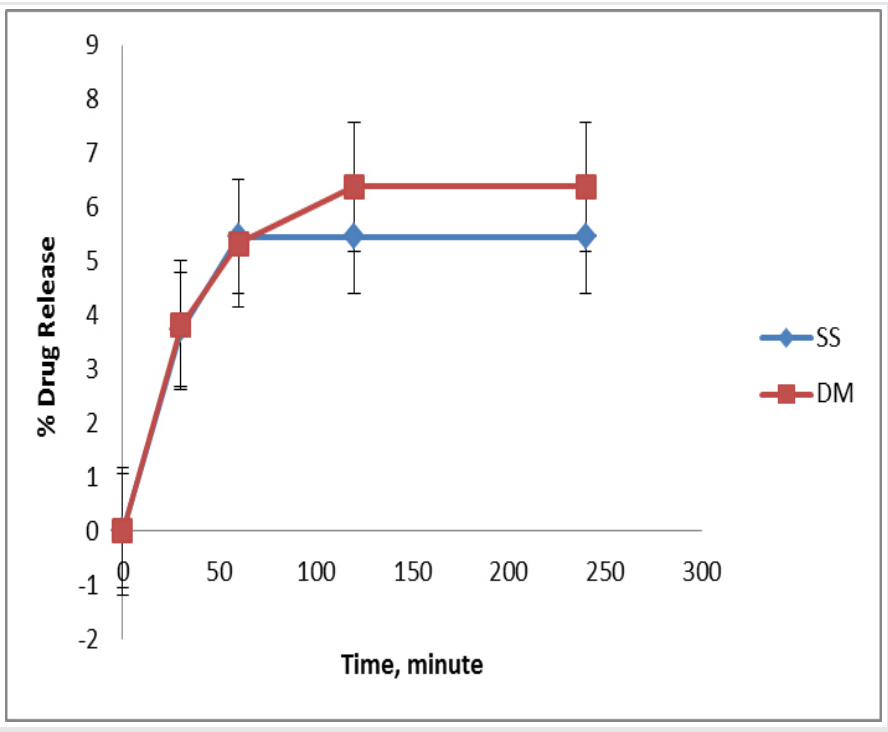

Figure 5. Comparative release profile of L-Dopa from nanoparticles using the DM and SS methods $(n=3)$. 
the hydrodynamics of the system when compared with the nanoparticles in the dialysis bag to the formulation dispersed in a flask (25).

The similarity factor $(f 2)$ is a measurement of the similarity in the percent (\%) dissolution between the two profiles (26). The difference factor $(f 1)$ is proportional to the average difference between the two profiles. FDA guide proposes that $f 1<15$ and $f 2>50$ to indicate equivalence in dissolution profiles (27).

$f 2=50 x \log \left(\left[1+(1 / \mathrm{n}) \sum_{\mathrm{t}=1}^{\mathrm{n}}\left(\mathrm{R}_{\mathrm{t}}-\mathrm{T}_{\mathrm{t}}\right)^{2}\right]^{-0.5} \times 100\right)$

$f 1=\left[\sum_{\mathrm{t}=1}^{\mathrm{n}}\left(\mathrm{R}_{\mathrm{t}}-\mathrm{T}_{\mathrm{t}}\right) / \sum_{\mathrm{t}=1}^{\mathrm{n}} \mathrm{R}_{\mathrm{t}}\right] \mathrm{x} 100$

As shown in Table 12, the difference in the L-Dopa release kinetics was not significant for both methods $(f 1<15$ and $f 2$ $>50)(24,28)$. Comparison of the dissolution profiles was held with the two tailed $\mathrm{t}$-test. At all time intervals drug release (\%) was not different between test and reference methods $(\mathrm{p}=0,853$; $\mathrm{p}<0,05)$.

\section{CONCLUSION}

The validated methods were found to be simple, sensitive, accurate and precise. The results indicated that these methods are suitable for dissolution studies as well as routine quality control analysis of L-Dopa in nanoparticular formulations. DM and SS methods gave similar in vitro release profiles at acceptable precision $(<10 \%, S D)$. The SS method tended to show faster release rates from formulations than those observed using dialysis bag (Table 12). The difference between DM and SS methods in the release kinetics was considered not significant $(f 1<15$ and $f 2$ $>50$ ). The optimal method with respect to in vivo relevance in light of an in vivo in vitro corelation will need to be determined for further studies.

\section{Conflicts of interest}

The authors declare that there are no conflicts of interest.

\section{ACKNOWLEDGMENTS}

This study is a part of our project which was supported by TUBITAK (THE SCIENTIFIC AND TECHNOLOGICAL RESEARCH COUNCIL OF TURKEY; Project No:116S639)

\section{REFERENCES}

1. Zhou YZ, Alany RG, Chuang V, Wen J. Optimization of PLGA nanoparticles formulation containing L-DOPA by applying the central composite design. Drug Dev Ind Pharm. 2013;39(2):321-30. doi: 10.3109/03639045.2012.681054. PubMed PMID: 22607101.

2. Sharma S, Lohan S, Murthy R. Formulation and characterization of intranasal mucoadhesive nanoparticulates and thermo-reversible gel of levodopa for brain delivery. Drug development and industrial pharmacy. 2014;40(7):869-78.

3. Luinstra M, Grasmeijer F, Hagedoorn P, Moes JR, Frijlink HW, de Boer AH. A levodopa dry powder inhaler for the treatment of Parkinson's disease patients in off periods. Eur J Pharm Biopharm. 2015;97(Pt A):22-9. doi: 10.1016/j.ejpb.2015.10.003. PubMed PMID: 26453913.
4. Vasa DM, Buckner IS, Cavanaugh JE, Wildfong PL. Improved Flux of Levodopa via Direct Deposition of Solid Microparticles on Nasal Tissue. AAPS PharmSciTech. 2017;18(3):904-12. doi: 10.1208/ s12249-016-0581-4. PubMed PMID: 27380436.

5. Pahuja R, Seth K, Shukla A, Shukla RK, Bhatnagar P, Chauhan LKS, et al. Trans-blood brain barrier delivery of dopamine-loaded nanoparticles reverses functional deficits in parkinsonian rats. ACS nano. 2015;9(5):4850-71.

6. Nedorubov A, Pavlov A, Pyatigorskaya N, Brkich G, Aladysheva Z. HPLC-MS/MS Method Application for the Determination of Pharmacokinetic Parameters of Intranasal Delivered L-DOPA in Rats. Journal of Pharmaceutical Sciences and Research. 2018;10(10):248992.

7. Gambaryan P, Kondrasheva I, Severin E, Guseva A, Kamensky A. Increasing the Efficiency of Parkinson's Disease Treatment Using a poly (lactic-co-glycolic acid)(PLGA) Based L-DOPA Delivery System. Experimental neurobiology. 2014;23(3):246-52.

8. Souza PRdSe, Carvalho JMd, Albert ALM, Moreira JC, Leandro KC. Development and validation of a method for the determination of valproic acid in pharmaceutical formulations by high performance liquid chromatography with diode array detection (HPLC-DAD). Vigilância Sanitária em Debate. 2013;1(1). doi: 10.3395/vd.v1i1.16.

9. Fuster J, Negro S, Salama A, Fernández-Carballido A, Marcianes P, Boeva L, et al. HPLC-UV method development and validation for the quantification of ropinirole in new PLGA multiparticulate systems: Microspheres and nanoparticles. International journal of pharmaceutics. 2015;491(1-2):310-7.

10. Raut PP, Charde SY. Simultaneous estimation of levodopa and carbidopa by RP-HPLC using a fluorescence detector: its application to a pharmaceutical dosage form. Luminescence. 2014;29(7):762-71. doi: 10.1002/bio.2618. PubMed PMID: 24399763.

11. Konduru N, Madhuri G. STABILITY INDICATING METHOD OF CARBIDOPA AND LEVODOPA ASSAY IN CARBIDOPA, LEVODOPA AND ENTACAPONE FILM COATED TABLETS BY RP-HPLC.

12. Dhawan R, Ravi S, Subburaju T. Compatibility and stability studies of levadopa, carbidopa, entacapone and natural bioenhancer mixture. IJPAR. 2014;3(4):474-81.

13. Reddy BJC, Sarada NC. A Simple Validated Stability Indicating RPHPLC Method for the Determination of Three Antiparkinsonism Compounds in Oral Contraceptive Tablet Formulations. International Journal of ChemTech Research. 2017;10(3):636-46.

14. Gao X, Tao W, Lu W, Zhang Q, Zhang Y, Jiang X, et al. Lectinconjugated PEG-PLA nanoparticles: preparation and brain delivery after intranasal administration. Biomaterials. 2006;27(18):3482-90.

15. Junnotula V, Licea-Perez H. Development and validation of a simple and sensitive method for quantification of levodopa and carbidopa in rat and monkey plasma using derivatization and UPLC-MS/MS. J Chromatogr B Analyt Technol Biomed Life Sci. 2013;926:47-53. doi: 10.1016/j.jchromb.2013.03.004. PubMed PMID: 23548675.

16. ICH. Q2(R1) Validation Of Analytical Procedures: Text And Methodology. 2005. 
17. Piazza J, Hoare T, Molinaro L, Terpstra K, Bhandari J, Selvaganapathy $\mathrm{PR}$, et al. Haloperidol-loaded intranasally administered lectin functionalized poly (ethylene glycol)-block-poly (D, L)-lacticco-glycolic acid (PEG-PLGA) nanoparticles for the treatment of schizophrenia. European Journal of Pharmaceutics and Biopharmaceutics. 2014;87(1):30-9.

18. Pappert EJ, Buhrfiend C, Lipton JW, Carvey PM, Stebbins GT, Goetz CG. Levodopa Stability in Solution: Time Course, Enviromental Effects, and Practical Recomendations for $\mathrm{Cl}, \mathrm{n}$,cal Use. Movement Disorder Society. 1996;11(1):24-6.

19. Bhatnagar P, Vyas D. Stability Indicating HPLC Method for Simultaneous Estimation of Entacapone, Levodopa and Carbidopa in Pharmaceutical Formulation. Journal of Chromatography \& Separation Techniques. 2015;06(07). doi: 10.4172/21577064.1000304 .

20. Ermer J, Miller JHM. Method validation in pharmaceutical analysis: A guide to best practice: John Wiley \& Sons; 2006.

21. Mendez ASL, Steppe M, Schapoval EES. Validation of HPLC and UV spectrophotometric methods for the determination of meropenem in pharmaceutical dosage form. Journal of Pharmaceutical and Biomedical Analysis. 2003;33(5):947-54. doi: 10.1016/s07317085(03)00366-2.

22. Ravani L, Sarpietro MG, Esposito E, Di Stefano A, Sozio P, Calcagno $\mathrm{M}$, et al. Lipid nanocarriers containing a levodopa prodrug with potential antiparkinsonian activity. Materials Science and Engineering: C. 2015;48:294-300.

23. Mehta J, Patidar K, Patel P, Kshatri N, N. V. Development \& validation of an in vitro dissolution method with HPLC analysis for misoprostol in formulated dosage form. Anal Methods. 2010;2:72-5. doi: 10.1039/b9ay00188c.

24. D’Souza SS, DeLuca PP. Methods to assess in vitro drug release from injectable polymeric particulate systems. Pharm Res. 2006;23(3):46074. doi: 10.1007/s11095-005-9397-8. PubMed PMID: 16400516.

25. D'Souza SS, DeLuca PP. Development of a dialysis in vitro release method for biodegradable microspheres. AAPS PharmSciTech. 2005;6(2):E323-E8. doi: 10.1208/pt060242.

26. Gonjari DI, Karmarkar AB, Hosmani AH. Evaluation of in vitro dissolution profile comparison methods of sustained release tramadol hydrochloride liquisolid compact formulations with marketed sustained release tablets. Digest Journal of Nanomaterials and Biostructures 2009;4(4):651 - 61. Epub 2009.

27. FDA. Dissolution Testing of Immediate Release Solid Oral Dosage Forms. 1997.

28. Shazly G, Nawroth T, Langguth P. Comparison of Dialysis and Dispersion Methods for In Vitro Release Determination of Drugs from Multilamellar Liposomes. Dissolution Technologies. 2008. doi: dx.doi.org/10.14227/DT150208P7. 